\title{
Towards a sustainable campus: working together to achieve the green campus flag on the UDC peripheral campus of Ferrol
}

\author{
Ana Ares-Pernas, Carmen Coronado Carvajal, Alfonso Gomis Rodríguez, María Isabel \\ Fernández Ibáñez, Vicente Díaz Casás, María Sonia Zaragoza Fernández, María Sonia \\ Bouza Fernández, Manuela del Pilar Santos Pita, Antonio Domingo García Allut, María \\ Pilar Comesaña Pérez, María Jesús Caínzos López, Belén Feal Cabezón, Araceli Torres \\ Miño
}

\begin{abstract}
Purpose. This paper aims to present and describe the main actions carried out in six different faculties and common areas such as cultural and research centres and administrative buildings in the Ferrol campus at the University of A Coruña to achieve the second green flag on a Galician University.

Design/methodology/approach. A case study describing the steps for implementing a green campus programme in a medium-size, young university campus integrated into a small city. An Environmental Campus Committee was created to assess the main factors that affect environmental footprint, discuss sustainability initiatives and develop a guide to action regarding different goals related to sustainable transport options, energy, water conservation and waste reduction. The actions included several fields such as education, circular economy and healthy life and involved the on and off-campus community.

Findings. The programme achieved a decrease in water consumption and electrical energy. An important change in educational values and behaviours regarding sustainability was observed in and out of the campus community. The measurements adopted mainly in waste management, mobility and education led the Ferrol campus to achieve a green campus flag on November 2019.

Originality/value. This experiment can serve as a guide to establish the Green Campus philosophy in other similar university campuses.
\end{abstract}

\section{Keywords}

Higher education, Action plan, Green flag, Peripheral campus, Sustainability development goals

\section{Paper type}

Case study 


\section{Introduction}

Currently, one of the most important goals in universities is to serve as an example for communities and society to minimize greenhouse gas emissions and be eco-friendly (Abu Qdais et al., 2019; Adom $\beta$ net et al., 2019; Choi et al., 2017; Sima et al., 2019) and to improve people's health and well-being. As university students are society's future decision-makers, the institution must ensure that undergraduates and graduates have the necessary knowledge and skills to work considering the environment and introduce them to the sustainable development goals (SDG) developed by the United Nations (Hamzah et al., 2018; Yuhlong et al., 2018). Like other public institutions, the University campus buildings contribute largely to a city's carbon footprint because of its great water and energy consumption, air pollution, etc. (Abu Qdais et al., 2019; Keoy et al., 2012; Leal Filho et al., 2015; Sima et al., 2019), showing the need for a plan to transform energy-wasteful university campuses into green campuses. In February 2014, the University of A Coruña (UDC) signed a collaboration agreement with the Association of Environmental and Consumer Education (ADEAC), a member of the International Foundation for Environmental Education (FEE), to implement ecological management procedures under the Green Campus flag (UDC, 2019). Green Campus is a new programme that adapts the philosophy, methodology and experience of Eco-schools to the specific needs and problems of the university environment. Eco-Schools is the largest global sustainable school programme - it starts in the classroom and expands into the community by engaging the next generation in action-based learning, that is, engaging the youth of today to protect the planet of tomorrow (FEE, 2019).

(1) Its goals revolve around 10 areas of action:

(2) optimization of water and energy consumption;

(3) reduction of waste generation and selective collection;

(4) special attention to the waste of electrical and electronic equipment (WEEE);

(5) atmospheric, acoustic and light pollution;

(6) sustainable mobility;

(7) healthy eating;

(8) biodiversity;

(9) green purchasing, fair trade and responsible consumption;

(10) participation, environmental awareness and volunteering; and

(11) greening the curriculum in teaching and research.

The UDC comprises two campuses: one in the city of A Coruña and another one in the city of Ferrol. In recent years, the UDC has made great efforts to obtain and maintain the Green flag in some of its faculties on the Campus of A Coruña. As such, different colleges at the Ferrol campus have been working during the past year to obtain the second green flag at a Galician University Campus. Such an initiative is even more valuable because this is a secondary, medium size, young campus integrated into a small city with the respective problems regarding communication and transport that it might entail. To this end, a plan was designed to address not only environmental issues such as energy consumption or waste management but also education, healthy life and the relationship with the local community.

\section{Background}

Over the past few years, many universities have worked to be more sustainable, using green technology and clean energy to achieve a zero-energy building (Abidin et al., 2019); others have focused on making better use of the campus by using the Internet of Things for a learning environment (Voore et al., 2020). Universities also explored the propensity of university students to use different sustainable modes of transport (Cattaneo et al., 2018), as well as diffusing and promoting the use of different measures to reinforce the public transport system or the use of different types of electric vehicles from the University Campus to downtown and suburban areas (Brenna et al., 2020). Some authors also describe actions related to food supply chains (Bryan and Middlecamp, 2017). 
The literature gives us several examples of Green Campus Offices focused on adopting actions either to be more sustainable or to carry out measures within a sustainability programme. A study by Zen et al. (2016) discusses the potential of a waste minimization approach for campus sustainability and shows the first-hand experience of the sustainability science approach implemented in campus sustainability. Regarding the Green Campus Flag, Ryan-Fogarty et al. (2016) describe the evolution and development of the Green Campus programme in Ireland, presenting a flexible, dynamic framework that international policymakers and NGOs can emulate to promote lasting ESD programmes that are responsive, as well as responsible. Kirrane et al. (2016) focus on University College Cork, the first university awarded the Green flag, describing its experience, tools and recommendations in the process of obtaining a STARS Gold rating. Their experience can be useful for campuses embarking on this programme of the Association for the Advancement of Sustainability in Higher Education, and for assessing sustainability in higher education. Amidst these examples that can help in the process of obtaining the Green Flag or in implementing sustainability measures in higher education, our case study stands out for being developed on a secondary campus involving all citizens, including people with special needs, being the first of its kind.

Regarding students, different measures were taken to introduce the SDGs at different levels of education and to assess the skills achieved (Albareda- Tiana et al., 2018). Sandström et al. (2018) describe a method that can be used as an indicator of sustainability, innovation and learning during the process of participatory change and in evaluating the outcome, which could be useful in the process of obtaining the Green Campus flag.

Aware of the importance of preparing engaged citizens for the dynamic and environmental conditions of this century (Alexander and Pushnik, 2017), some universities have collaborated with the municipal administration or community stakeholders and have even introduced social justice as an integral part of sustainability (Kruger et al., 2018; Kowalski and Herstek, 2018). However. as Kruger et al. (2018) explain, students, find this relation between sustainability and social justice difficult to identify. While terms such as "recycling" and "economic viability" were identified as integral to the concept of sustainability, items such as "reducing meat consumption" or "growing organic vegetables" were not.

To overcome this issue, most universities use the campus as a laboratory for developing necessary sustainability-related skills in their students, professors and staff, involving them in sustainable learning scenarios or sustainability-related service-learning programmes. Based on a methodology in which students achieve certain academic and cross-sectional competences on a given subject while performing tasks for the community's benefit (Yuhlong et al., 2018; Seban, 2013; Whitley, 2015), service-learning programmes have the potential to deeply affect student behaviour (Melaugh and Kindschuh, 2017), promote community relationship, offer the potential to solve social issues and provide an opportunity for students to engage with community partners (Benning et al., 2018). In fact, service-learning projects are useful tools for incorporating environmental concepts into courses to teach students about sustainability (Coleman et al., 2017), enriching curricula and making students aware of community problems (Hayes Lane et al., 2017).

Implementing sustainable development requires different measures that vary according to the institutional framework, highlighting that working on campus sustainability from different perspectives deserves investigation.

This study describes an organizational experience on the university campus in Ferrol. Because it is fully integrated into the city, all decisions regarding campus sustainability end up affecting the community, requiring that most decisions on transport or waste reduction issues be made in conjunction with local authorities.

Ferrol campus also comprises a University for older adults - with approximately 300 people enrolled and provides several services to the citizens. Whether through service-learning projects aimed at people with disabilities (Alzheimer's disease, Down syndrome or deafness), at risk of social exclusion or with mental illnesses or through the provision of podiatric care and psychological support to families with chronic illness at the School of Nursing and Podiatry, the Campus-community relationship is integral to its structure. Thus, to be inclusive, all activities and measures must consider the campus-city-community relationship and the diverse population that make up the university. 
Given this context, this case study of a fully integrated campus may be useful for others in similar conditions.

\section{Project description}

\section{The institution and participants}

Ferrol campus is a peripheral campus belonging to the UDC, a public institution of higher education and research located in the Northwest of Spain. Located in the third urban concentration of Galicia, the campus has six schools, totaling 11 undergraduate, 7 master's and 6 doctoral programmes. The campus is divided into two parts: the Polytechnic University School, outside the city and the main campus of Esteiro, installed among 67 tree species from a botanical garden in rehabilitated buildings of the former Navy Hospital (Plate 1).

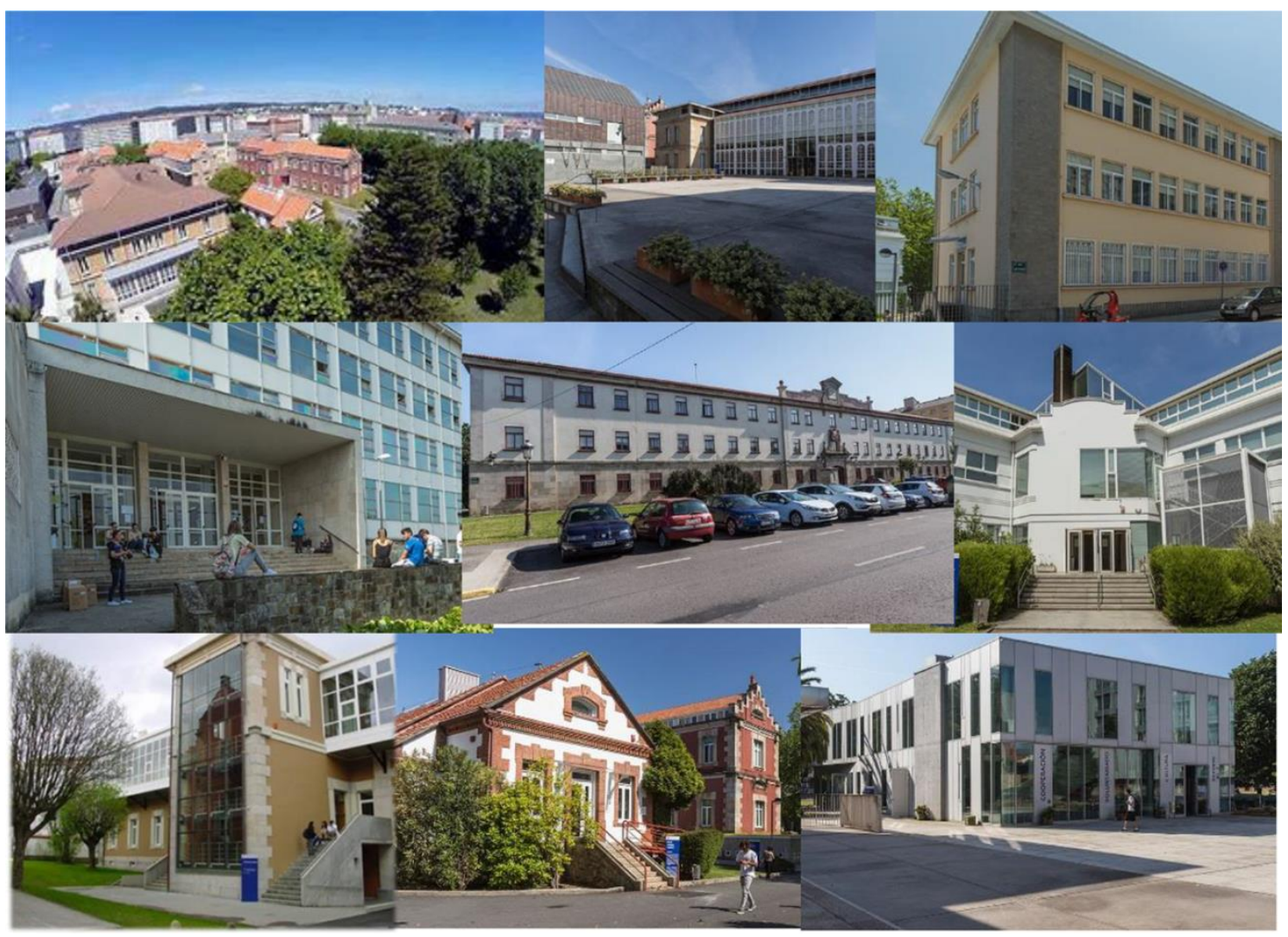

Plate 1. Ferrol campus buildings 
This case study focuses on a specific project that lasted two academic years - 2017/2018 and 2018/2019 during which the following group of faculties and common areas came together to obtain the Green flag for this campus:

(1) Vice-rector's Office and Social Responsibility:

- Administrative Building.

- $\quad$ Study-support Building.

- $\quad$ Restaurant and the University Cultural Centre.

- Technical Research Centre.

- University Library.

(2) Polytechnical University School.

(3) Higher Polytechnic School.

(4) University School of Industrial Design.

(5) Faculty of Labor.

(6) Faculty of Nursing and Podiatry.

(7) Faculty of Humanities and Documentation.

The project involved approximately 2,337 students, 120 administrative and service employees, 208 professors, the local council, different associations working with people with disabilities, the University for older adults and Ferrol citizens.

\section{Methodology}

This is a case study describing the first steps for implementing a Green Campus programme in a mediumsized, young campus integrated into a small city. At its inception, the study included all sectors, centres and people in the university community as sources of evidence to gain a holistic picture. Information was collected from collaborating and scholarship students, professors and administrative staff depending on the action analysed. To achieve its main objective of obtaining the Green Campus flag, the project underwent several steps:

- Application.

- Internal audits.

- Constitution of the campus committee.

- Action plan.

- Development of actions.

- $\quad$ Preparation of the report.

- $\quad$ Code of conduct.

- External audit.

After the two first steps performed by the University's Environment Office, in September 2017 an Environmental Campus Committee was created to assess the main factors that affect the environmental footprint, discuss sustainability initiatives and develop a guide to action. This committee comprised at least one member from each school and two agents from the common areas (Table 1). The project considered the 17 SDGs developed by the United Nations:

(1) no poverty;

(2) zero hunger;

(3) good health and well-being;

(4) quality education;

(5) gender equality;

(6) clean water and sanitation;

(7) affordable and clean energy;

(8) decent work and economic growth;

(9) industry, innovation and infrastructure;

(10) reduced inequalities;

(11) sustainable cities and communities; 
(12) responsible consumption and production;

(13) climate action;

(14) life below water;

(15) life on land;

(16) peace, justice and strong institutions; and

(17) partnerships for the goals.

Table 1. Committee members

\begin{tabular}{ll}
\hline Collective to which they belong & No. of participants \\
\hline & \\
Teachers & 11 \\
Students & 1 \\
Administration and service staff & 1 \\
Restaurant worker & 1 \\
Cultural society member & 1 \\
\hline
\end{tabular}

The actions that were implemented on Campus sought to address and work towards these objectives, as will be seen below.

The committee comprised the authors of this article. One professor represented each faculty, except for the Higher Polytechnical School, represented by three professors and the Faculty of Humanities and Documentation, represented by two professors and an administrative and service employee. Each faculty/common area had subcommittees composed of at least two students, one member of the administrative team and other professors, led by a committee member and responsible for carrying out the different tasks of the action plan in their respective School/Faculty/Centre.

Its first task was to write a document defining the main roles of each committee member, its operating rules regarding meetings, new members and the creation of subcommittees in each centre; the second step was to conduct an eco-audit of several aspects, to assess the starting point of the campus.

In collaboration with head members or administrative and service staff, a member of the Committee conducted a survey including different questions about energy, water, wastes, pollution, mobility, procurement, the greening of the curriculum and environmental policy in each school and common building to assess the initial situation. From the obtained results, the committee defined an Action Plan including the following thematic areas:

- Optimization of water and energy consumption.

- Reduction of waste generation and selective collection.

- Atmospheric, acoustic and light pollution.

- $\quad$ Sustainable mobility.

- Healthy eating.

- Green purchasing, fair trade and responsible consumption.

- $\quad$ Participation, awareness and environmental volunteering.

- Greening the curriculum in teaching and research. 
From these thematic areas, the Committee designed a strategic plan with actions in seven areas, each related to some SDG:

- $\quad$ Environmental statement and code of conduct (Goal 17).

- $\quad$ Circular economy (Goals 12 and 13).

- $\quad$ Energy efficiency (Goals 4, 6, 12 and 13).

- $\quad$ Environmental unit (Goals 3, 4, 11, 13).

- Environmental and social education (Goals 4, 5, 10,12 and 16).

- $\quad$ Community communication (Goal 11).

- Healthy life (Goal 3).

Thus, with the development of different actions, 10 of the 17 sustainable development goals were addressed. After writing the environmental statement and code of conduct informing the entire campus community about the project, the committee appointed representatives for each case and defined the indicators to measure the success of each action. Here we present the main results obtained in some of these actions, divided into three main points, namely, circular economy, energy efficiency and environmental unit deal with the actions aimed at reducing the consumption of paper, energy and water and educating the university community in this regard; Healthy life discusses the actions taken on and off the campus for this purpose; and Environmental and social education involves all the activities developed to educate both the university community and the citizens of Ferrol.

\section{Results}

\section{Circular economy, energy efficiency and environmental unit}

Regarding the circular economy, the project introduced changes in the work methodology in each School, Faculty and Centre to avoid paper consumption, with measures involving people on and off-campus. All procedures related to the university started using intranet or e-mail, while the entire UDC community adopted Microsoft Office 365 or Moodle for collaborative works. Older adults who were studying at the Senior University at the time needed the help of their families to start using these tools, in addition to the training offered at the university.

Educators included several instructions in the teaching guides to avoid paper consumption:

- $\quad$ Classwork must be delivered in electronic format via Moodle or e-mail.

- In cases where the paper is needed, printing must be on both sides and recycled paper must be used.

- $\quad$ Draft printing must be avoided.

Copiers and printers were placed in common areas to avoid individual use and users were given a personal code to access the machines, thus controlling individual consumption and reducing the number of copies. Next to each copier and printer, a poster noting the importance of reducing paper was attached. The administrative and service staff monitored compliance with these rules at each Centre/Faculty/School, while educators participated by not accepting works or tasks in the paper. In addition to reducing the amount of paper consumed by $50 \%$, these actions also benefited the students' families, reducing expenses with paper and copies.

Each centre manager received instructions explaining the need for purchasing with responsible ecological criteria, that is, green purchasing. The centre's managers and administrative staff contacted their common suppliers by e-mail asking about the possibility of exchanging their common products for sustainable ones. Several sustainable products were purchased such as recycled paper and LED lamps, which completely replaced the previous ones at the end of their useful life. 
Regarding water saving, the Environment Office and the Committee representative at each Centre/Faculty/School conducted a water audit. Each tap and cistern had its water flow measured and, depending on the feasibility, each tap received a diffuser or had its water flow adjusted to save water. In addition, water-saving and awareness posters were posted next to the taps. Table 2 shows the measures applied and the respective percentage of water-saving.

Table 2. Water audit

\begin{tabular}{|c|c|c|c|c|c|}
\hline Building & Taps & $\begin{array}{l}\text { Difussers (D) } \\
\text { tap adjust. (T) }\end{array}$ & $\%$ reduction & Cisterns & $\%$ global reduction \\
\hline Vice-rectory & 8 & $\mathrm{~T}$ & 79.0 & 8 & 79.0 \\
\hline Main auditorium & 6 & $\mathrm{~T}$ & 76.3 & 11 & 60.5 \\
\hline Research centre & 12 & Both & 78.9 & 12 & 40.8 \\
\hline Labor sciences & 32 & Both & 72.4 & 44 & 65.3 \\
\hline Humanities & 21 & $\mathrm{~T}$ & 68.0 & 28 & 37.7 \\
\hline Higher polytechnical & 38 & $\mathrm{~T}$ & $59.4 *$ & 41 & $10.1^{*}$ \\
\hline Study centre & 8 & $\mathrm{~T}$ & $49.9^{*}$ & 17 & $9.6^{*}$ \\
\hline Library & 14 & Both & 68.3 & 17 & 45.6 \\
\hline
\end{tabular}

Note: *Not all the taps were adjusted

The measures reduced water consumption by between $10.1 \%$ (for the adjusted taps) and $79 \%$. With the implementation of the measures the water flow values went from 7.6 and $14.4 \mathrm{~L} / \mathrm{min}$, with maximum values of $20 \mathrm{~L} / \mathrm{min}$, to 1.6 and $6.8 \mathrm{~L} / \mathrm{min}$, with an average of $3.2 \mathrm{~L} / \mathrm{min}$.

Regarding electricity and heating, the Committee developed an awareness campaign to avoid leaving the lights on. Stickers with the text "turn on only if necessary" were pasted next to the switches.

A novel energy efficiency project was developed for the Campus (Chalfoun, 2014; Soares et al., 2015), called "pilot project for scalable energy management and efficiency at Ferrol campus (Smart Campus Project)" and sent to a public tender. This project integrates, for the first time, teaching and research on energy efficiency and water management via a cloud platform specially designed by Campus engineers, which manages a database fed by signals generated by network automata, sensors and analysers that will be placed in each building of the Ferrol campus. This platform will allow UDC's maintenance, adapting the energy installations to ensure thermal comfort avoiding unnecessary expenses, managing consumption according to the operations calendar of each building and avoiding waste. The platform is also accessible to educators from different areas and, thus, a single online unit with different user profiles could be used for research and specific teaching projects in more than 20 programmes in the areas of engineering, health or documentation, among others. As the platform uses free software, it would be eligible for use in other institutions. We expect the Smart project to have a return period of 3 years and an estimated $40 \%$ consume reduction, with the greatest benefits of its implementation in the areas of education and research on sustainability, energy efficiency and the environment.

As for the selective collection, each Campus building involved in the experiment received five recycling bins - plastic, paper and cardboard, glass, organic and solidarity caps - and three specific bins for collecting batteries, toner and electronic devices. A bulletin board and a WhatsApp group were created for each school to publicize all actions related to the Green Campus. (Plate 2) 


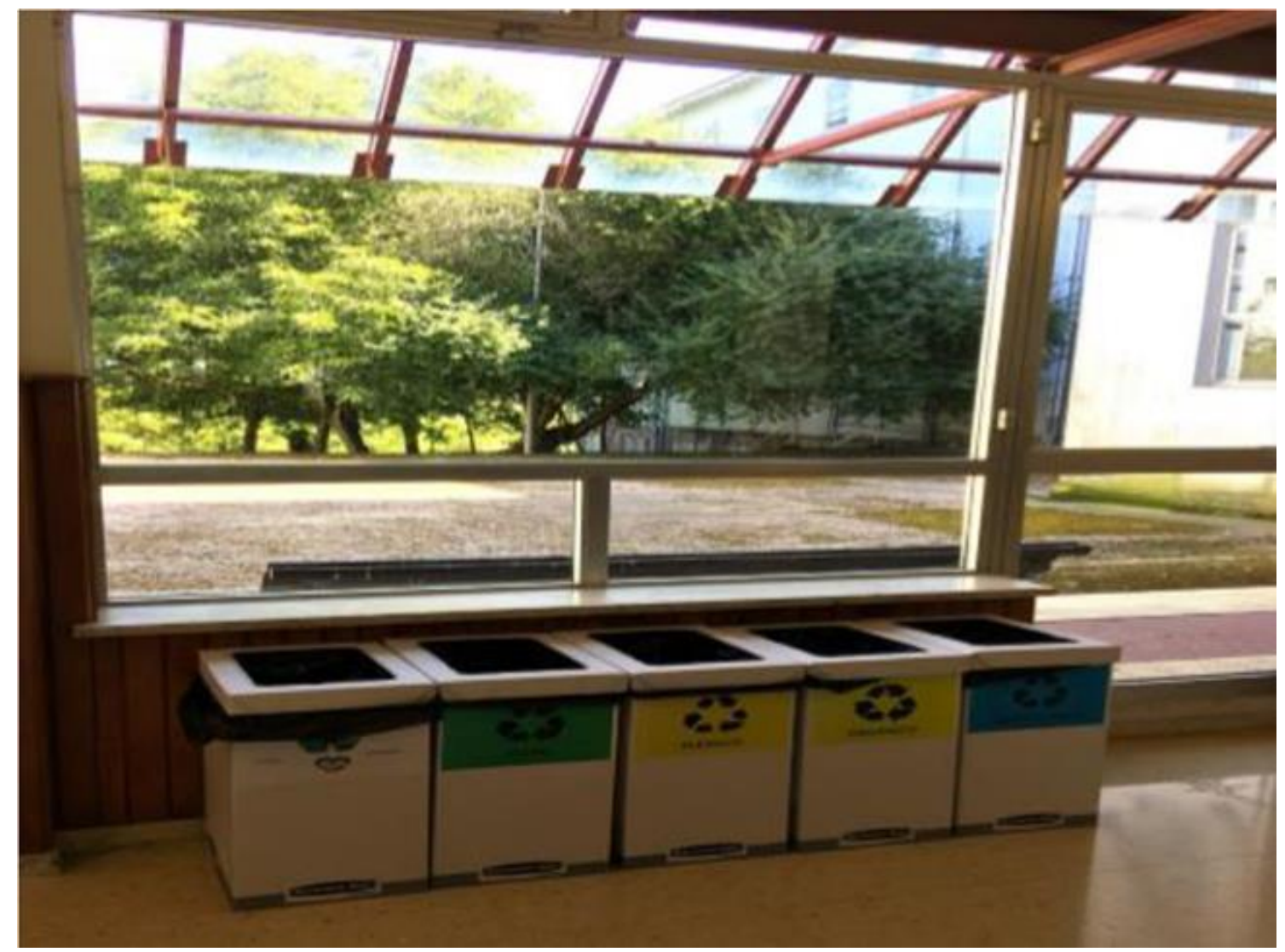

Plate 2. Recycling bins

Several training and awareness-raising actions and activities in waste management were carried out:

(1) Visit a waste management unit: Industrial Engineering students. On this visit, the students had the opportunity to learn about the recycling process of plastic waste after being sorted in specific bins. This further encourages them to properly separate plastics on Campus.

(2) Visit a treatment station: Nursing and Podiatry students.

(3) Conference cycle on the environment (Plate 3):

- "Water audit at home and in schools". This conference explained different strategies for saving water at home and in schools, as well as the impact of water waste on ecosystems.

- "The role of Higher Education in Sustainable Development. ODS 2030". The lecture explained the role of the university in bringing students closer to different environmental aspects such as sustainable development, ecological footprint, sustainable development goals, among others.

- "Plastic materials recycling and reuse workshop". The first part of the workshop exposed the importance of reduction, recycling and reuse, especially of plastic materials and addressed other topics such as disposable plastic, biopolymers, biodegradable plastic and microplastic. Each commodity plastic, its properties and Plastic Identification code was introduced. In the second part, the speakers conducted a mechanical recycling experiment. Using an injection moulding machine, new parts were obtained from bottle caps. The students then had the opportunity to work on their own with the injection moulding machine to create recycled parts, which served to understand the process.

- "Eco-design with plastic". In this lecture, an expert in the field explained to the attendees the importance of eco-design in the development of new products. Other 
topics such as circular economy, ecological footprint, green purchasing and product life cycle were also addressed.

- "Sustainability and green job sites". The lecture introduced listeners to the current change in the ways of producing, distributing and consuming, as well as new opportunities for "green jobs".

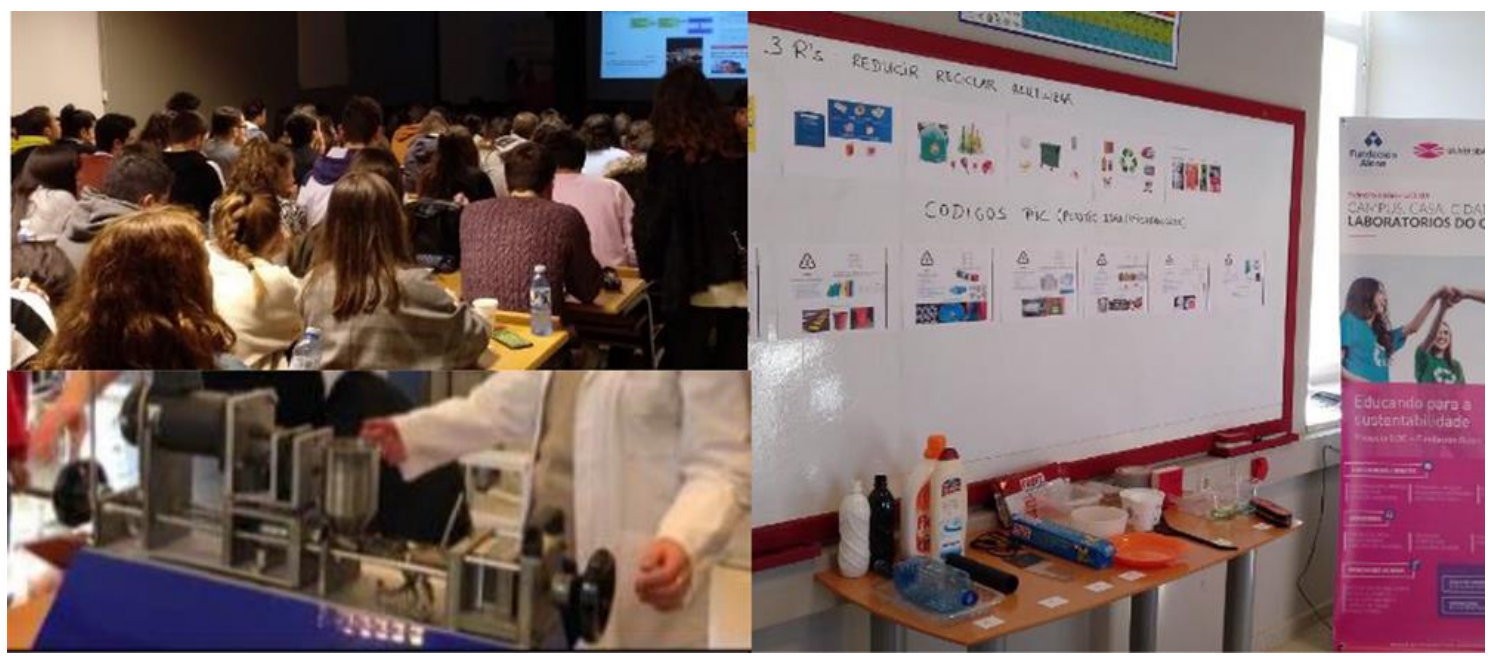

Plate 3. Photographs of conferences

All conferences were open to the general public, and according to data from the university's administrative body, about $10 \%$ of the 423 participants did not attend the university. After each talk, the coordinators delivered surveys to all attendees to evaluate their level of satisfaction. The committee understands that with these recycling actions, the selective collection was fully implemented.

Regarding mobility, three actions were taken to favour mobility at Ferrol campus. The first was a campaign to encourage cycling, the second was the installation of bicycle stands on the Campus and the last was a Mobility Plan developed in collaboration with the city's municipality (Table 3). This document includes all actions developed to encourage a sustainable public space (public transport, pedestrian areas, cycle paths, urban planning, etc.) (Cruz et al., 2017). 
Table 3. Mobility measures

\begin{tabular}{|c|c|}
\hline Mobility & Measure \\
\hline \multirow[t]{2}{*}{ Pedestrians } & Remove architectural barriers \\
\hline & Humanize pedestrian spaces (green and rest areas) \\
\hline Bicycle & Cycle lanes, parking, rental zones and campaigns \\
\hline Public transport & Improve the quality of service inside and outside of the city \\
\hline Private vehicle & $\begin{array}{l}\text { Promote car sharing and public transport, improve public and private parking (cars and motorcycles), hourly } \\
\text { controlled parking, promote green cars }\end{array}$ \\
\hline $\begin{array}{l}\text { Urban distribution of } \\
\text { goods }\end{array}$ & Regulate hours and spaces \\
\hline Road safety & Improve signage \\
\hline Environment & Promote green solutions \\
\hline Technology & $\begin{array}{l}\text { Improve technology solutions to reduce energy consumption and waste (cards for parking, transport on demand and } \\
\text { traffic line systems) }\end{array}$ \\
\hline Urban planning & Change the urban planning to adopt the new measures \\
\hline $\begin{array}{l}\text { Information, training and } \\
\text { education }\end{array}$ & Campaigns and training for citizens \\
\hline
\end{tabular}

\section{Healthy life}

Health is an extremely important issue to be considered when attending a Campus and a particularly relevant item for sustainable development goals and, thus requires certain measures. Firstly, the university has a health surveillance service that annually examines all workers, both faculty and administrative and service staff, being evaluated annually by the people involved.

The UDC has an Occupational Risk Prevention Service that serves to:

- $\quad$ Assess job risks.

- $\quad$ Provide preventive information.

- $\quad$ Encourage the use of personal protective equipment.

- $\quad$ Provide special training related to occupational hazards

- $\quad$ Investigate work accidents.

- Radon assessment on-campus buildings.

To teach emergency procedures for the community, an expert conducted a first aid and automated external defibrillator (AED) workshop for the entire campus community at the School of Nursing and Podiatry. (Figure 1) 


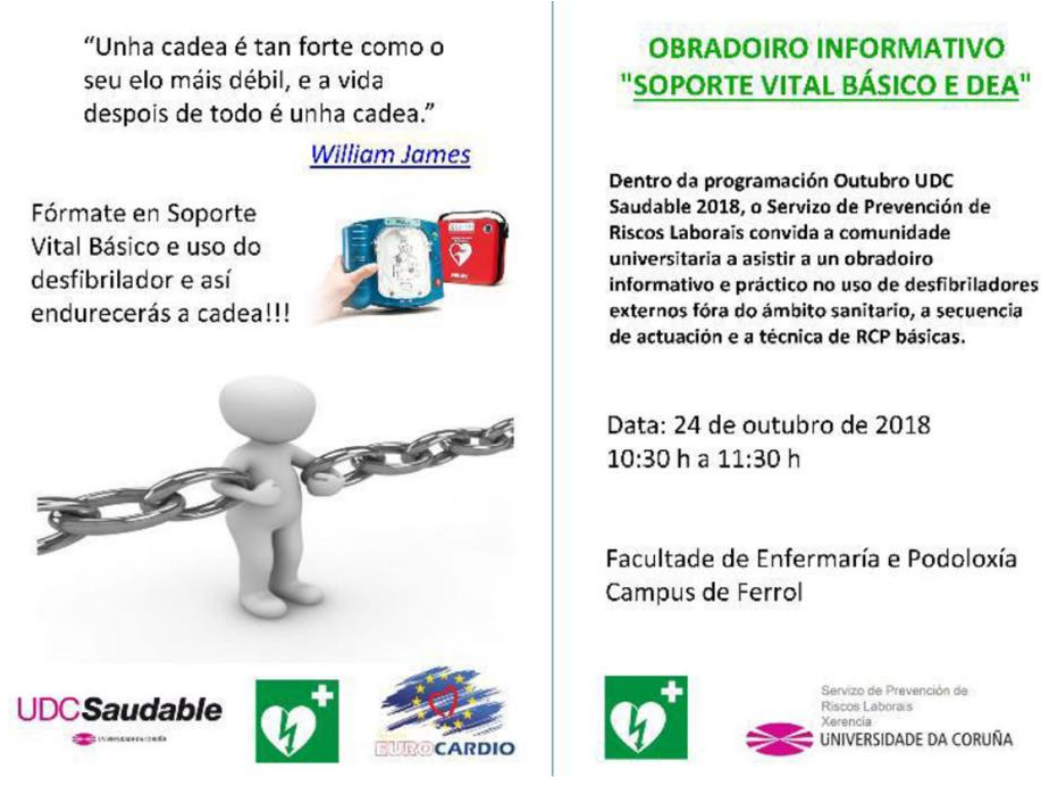

Figure 1. Workshop with AED

The UDC Health Office organized several events related to healthy living for the entire university community and the general population at the campus such as:

(1) Conference and healthy break at the Faculty of Nursing and Podiatry.

(2) Healthy Breakfast at the University Podiatry Clinic.

(3) Photocall "Healthy Instagram".

(4) "Healthy October" with different activities:

- Celebration of the National Day of Healthy Universities with the conference "impact of pseudosciences on health" at the School of Nursing and Podiatry.

- Collective barefoot photograph in the garden to celebrate International Podiatry Day.

- Hiking followed by a small healthy snack.

- Exhibition on solar energy: solar cookers (Plate 4). During this exhibition, students had the opportunity to build their own solar cook and cook different dishes.

- $\quad$ Tai Chi master class (Figure 2).

- Fruit picking (apples, lemons and nuts) in the gardens of the Polytechnical University School to assist social institutions: Economic kitchen and CÁRITAS, where people at risk of social exclusion or homeless are cared for and fed.

- The "5,000 blood donations" challenge. 


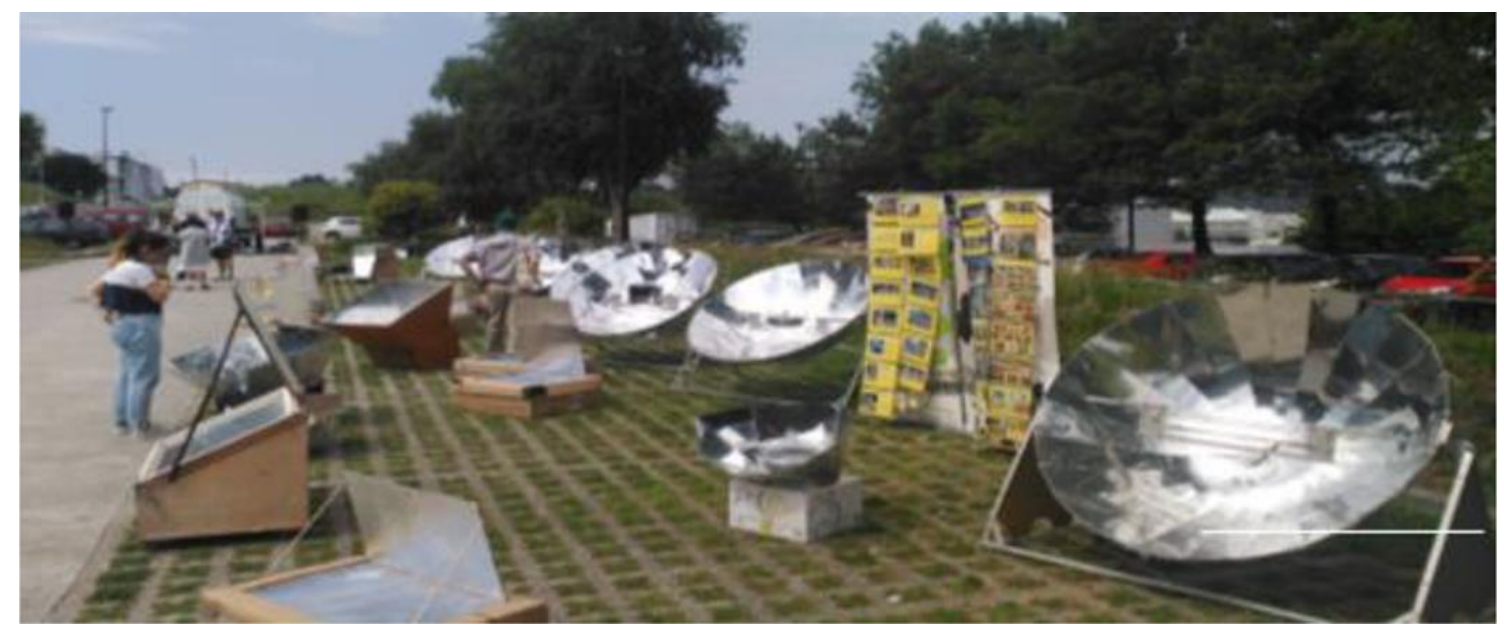

Plate 4. Solar cookers

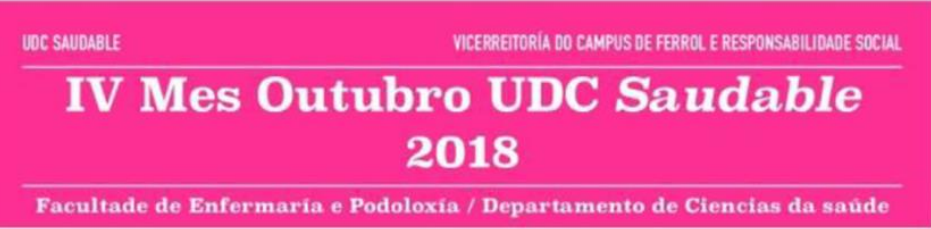

26 de outubro de

2018 ás 10:30 horas no Campus de Esteiro

Nos xardíns diante da cafetaría, no Centro Cultural Universitario $\left(1^{\circ}\right.$ piso arriba da cafetaría) se chove.

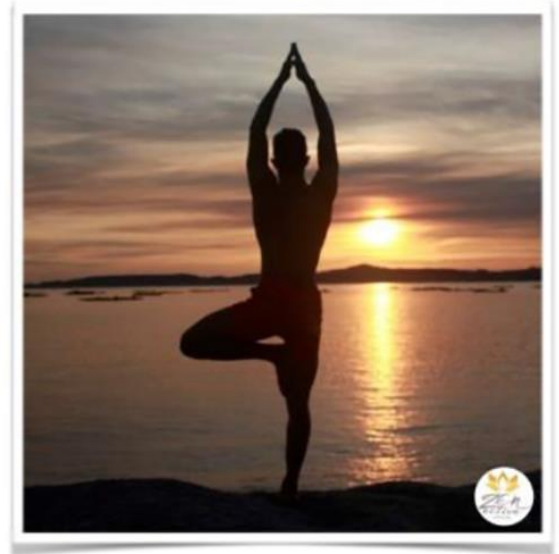

\section{MASTER CLASS DE TAICHI NO CAMPUS DE \\ FERROL}

A actividade fisica asocia múltiples beneficios para a saúde en todas as persoas, a calquera idade e tanto en mulleres como en homes. Con todo, cada vez hai máis xente que non se move o

suficiente, e isto débese, en gran parte, a que cambiamos o noso estilo de vida cara a un modelo máis sedentario.

http://www.estilosdevidasaludable.mscbs.gob.es/actividadFisica/introduccion/home.htm

Da man do instructor Fran Notario Andreu, de Zen Active, Licenciado en Ciencias da Actividade Física e Deportes, practicaremos esta arte marcial nos xardins do Campus de Ferrol (Esteiro)

Dirixido a: Todo o alumnado e a comunidade universitaria do Campus de Ferrol e poboación en xeral Responsables: Zen Active Arteixo e Green Campus Ferrol

$\gtreqless$ UNIVERSIDADE DA CORURA

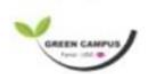

UDCSaudable

Figure 2. Tai Chi class poster 
A few measures carried out in the university restaurant, which is open to the whole community, during these two academic years deserve to be highlighted:

- Introduction of whole foods, vegetable proteins, local products, etc., in the menu.

- Correct management of used oil.

- $\quad$ Correct waste separation.

- Use of aromatic herbs instead of flavour enhancers.

- Use of seasonal items at a good price.

- Reducing the amount of fat and salt; offering alternatives for people with lactose or gluten intolerance.

- $\quad$ Sale of plastic water bottles prohibited.

- $\quad$ Reducing or avoiding takeaway packages.

The Green Campus committee developed a survey for the customers to evaluate these healthy eating measures, the results of which showed that the standards were being met.

To encourage physical activity, the committee pasted vinyls on-campus buildings, encouraging people to use the stairs instead of the elevator and conducted a contest to encourage people to cycle. Several physical activities were organized on the Campus. Table 4 shows the activities and their respective number of participants.

Table 4. Physical activities in the Ferrol campus

\begin{tabular}{ll}
\hline Activity & No. of participants \\
\hline & \\
Pilates & 31 \\
Personal training & 20 \\
Fitness & 57 \\
Fitboxing & 8 \\
Crosstraining & 12 \\
Surf & 7 \\
Fencing & 8 \\
Fitness room & 450 \\
Swimming & 80 \\
University leagues & 162 \\
\end{tabular}

The UDC Health Office used several advertising campaigns on the Campus to promote other healthy actions such as psychosocial well-being, sleep and rest, sexual health, actions against the use and abuse of alcohol, drugs and other addictions and pedagogical evaluation. To improve mental health, the office developed actions in collaboration with Mental Health FEAFES Galicia - an entity that promotes actions for a healthier and kinder university -, who provided information and assessment on mental health to UDC students. Drug addiction prevention had the collaboration of ASFEDRO, an entity that works with addicts, who offered information on drugs and advice on drug addiction to prevent such issues at the campus. Both measures represent a link between the university and community entities.

The School of Nursing and Podiatry offers two important services: The Family Care and Intervention Research Unit and the Podiatric Clinic. The former is family care and research service that offers free social, health and psychological care to families and people with various problems. Some of its activities are: evaluation and therapeutic treatment of young people at risk of social exclusion, multifamily group therapy programme with chronic physical illnesses or first aid courses in high schools. In many cases, the care provided complements other pharmacological or rehabilitation treatments provided by other professionals and institutions. The institution also has the role of training professionals and conducting research to improve the quality of family care. The Podiatry Clinic not only offers podiatry services but 
also supports patients with diabetes to prevent amputations. Students participate in these activities together with their professors as members of the workgroups of each unit.

\section{Environmental and social education}

Regarding education, in addition to guidelines for avoiding paper consumption, the teaching guide also provided measures related to sustainability, identity and gender equality such as:

- Use of sustainable resources.

- Gender and race equality in the classroom. No discrimination.

- Use of gender-neutral language in papers, the classroom, etc.

- Full integration of students with disabilities. The university has an Attention to Diversity Office that supports professors and students with disabilities in everything they need.

Aware that universities must teach students content, values and abilities (Dienhart, 2016; Disterheft et al., 2013; Pereira et al., 2014; Shribergt and Harris, 2012), different service-learning projects were developed by undergraduate students in Industrial Design Engineering and Product Development (EUDI) (Latib, 2017). These students attended two classes: "Fundamentals of Physics (PF)" and "Design and Processing of Polymers (DPP)". Another service-learning project was developed by students of Environmental Engineering (EE) of the Engineering Programme (EUP). Both projects collaborated with "Cáritas Diocesana Mondoñedo-Ferrol" (Cáritas) (religious entity), Mental Health "Ferrol, Eume e Ortegal" (AFAES), "Alzheimer Ferrolterra" (AFAL), "Teima Down Ferrol" (TEIMA) and "Ferrol Deaf Association" (AXF). Table 5 shows all service-learning activities and the people involved on and offcampus.

Table 5. Summary of service learning activities

\begin{tabular}{|c|c|c|c|c|c|}
\hline 1 & DPP & 16 & CÁRITAS & Homeless people & 18 \\
\hline 3 & $\mathrm{PF}$ & 12 & CÁRITAS & Risk of poverty children & 16 \\
\hline 4 & $\mathrm{PF}$ & 12 & AFAL & Alzheimer's disease & 36 \\
\hline 5 & $\mathrm{PF}$ & 12 & AFAES & Mentally ill & 36 \\
\hline 7 & $\mathrm{PF}$ & 18 & AXF & Deaf people & $10^{*}$ \\
\hline 8 & $\mathrm{EE}$ & 15 & CÁRITAS & Homeless people & 15 \\
\hline
\end{tabular}

Note: $*$ The videos can be useful for all the community so the actual range of the population affected could be higher

In each activity, students develop projects according to the needs of users, promoting social relationships between the university and specific social actors such as the homeless population (Plate 5):

- $\quad$ Activity 1: Students gave a seminar on plastic recycling and other basic concepts for homeless people, who need this information to apply for a job in the growing plastic recycling sector.

- Activity 2: Students prepared a Science Fair to teach physics concepts useful for the daily life of homeless people.

- $\quad$ Activity 3: Students taught children basic physics concepts (density, pressure, viscosity, etc.) using games and laboratory experiments to stimulate children's curiosity and interest in science. In the second part of the workshop, students taught about recycling, reuse and waste reduction, especially plastics, to promote responsible consumption, teaching social values and promoting respect for the environment. 
- Activity 4: Workshop on the selective collection and reuse and confection of new objects from waste with people with Alzheimer's. It aimed to promote contact with the current reality and stimulate memory and psychomotor activity using games and tasks related to recycling.

- Activity 5: Science and recycling fair for people with mental health issues (mainly schizophrenic) to teach content different from the usual ones (ceramic or wood workshops, gardening, laundry, cooking) and promote relationships with people off the entity centre.

- Activity 6: Adapted workshop on separation and reuse of plastic waste for people with Down syndrome.

- Activity 7: Production and editing of subtitled videos for the deaf in Physics and Recycling, which can be useful to the entire deaf community.

- Activity 8: Mobile collection campaign: workshop on electronic waste treatment for training homeless people.

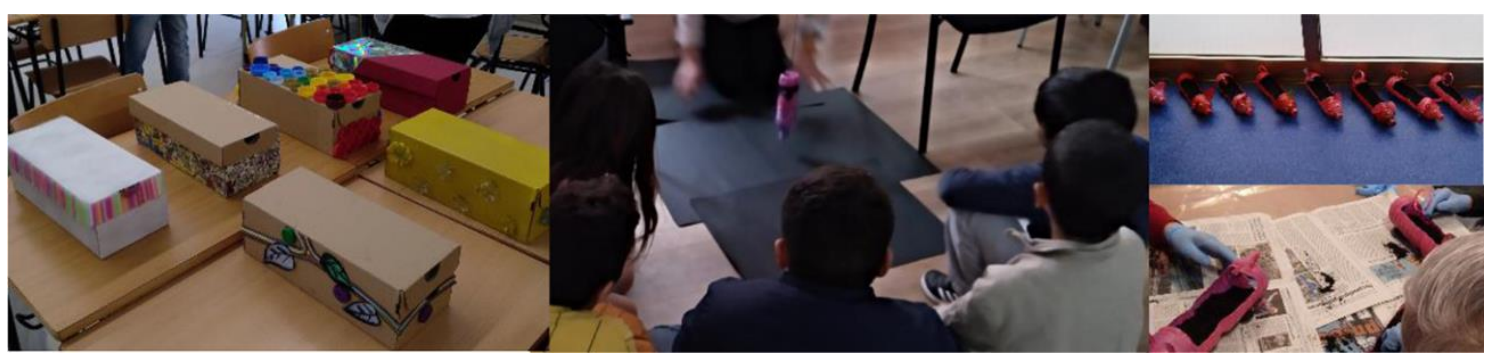

Plate 5. Photographs of service-learning activities

Before and after the activities, students, entities and users answered a survey evaluating its results and its impact on the community. From the comments in the surveys, the committee performed a qualitative analysis, with the information considered relevant coded according to its content and service-learning project, establishing categories and subcategories by the inductive method. Some categories were previously established considering the research question, but most emerged during the data analysis performed in the webQDA software, which allows researchers to carry out the process of reduction, categorization and coding (Cabedo et al., 2018; Ruiz-Montero et al., 2020; Ribeiro, 2019). To guarantee the reliability of the analysis results and reduce the risk of bias, three professors participated in the analytical process; an external reviewer participated at the end of the research process to ensure that the results were consistent. Below, we discuss some comments and final results.

Among the results obtained, some students' quotations considered in the data analysis stood out:

"A few hours were enough to come back to Earth and face reality". "I did not know the sad situation of these people”. (Student 5, TEIMA DOWN project, Moodle, 14 April 2018)

I learned a lot about recycling to use in my daily life and, obviously, when I start working. (Student 2, CÁRITAS project, Moodle, 18 April 2018)

I hope I have motivated the children to study so that they can live better. (Student 16, CÁRITAS project, Moodle, 5 May 2018)

Learning to teach meant that we had to pay more attention to the subject. I really learned a lot about recycling and environmental problems in general. (Student 1, AFAES project, Moodle, 23 April 2018) 
For the participating entities, the contact between users and university students was extremely positive:

I learned a lot and I enjoyed this with my new friends from the university. I will recycle at home. (User 4, TEIMA DOWN project, survey adapted, 14 April 2018)

I learned it easier than in class. I enjoyed doing the activities. (Child 10, CÁRITAS project, survey, 18 April 2018)

What impressed me most is that they treated me like a normal person who doesn't live on the street. (Homeless person 16, CÁRITAS project, survey, 5 May 2018)

I studied engineering before my illness. I liked being in class again. I really learned a lot about recycling and environmental issues in general. (Adult 1, AFAES project, survey, 23 April 2018)

Regarding people with mental issues and TEIMA Down, the therapist emphasized the importance of social contacts for this population. People with Alzheimer's remembered students from one recycling session to another; children at risk of social exclusion recognized they learned more with university students than in school, which is related to being with young people and learning by doing. The materials provided to deaf users were considered very useful by the association, but the most important for them was that students, future product designers, were attentive to their needs and could consider them in their professional future. There is still much to be done in adapting society to the deaf community, and thus professionals must be aware of these special needs. As highlighted by User 4, all the participants will transmit what they have learned about recycling in their homes, increasing the network of people concerned about the environment.

The University School of Industrial Design developed two additional projects: a sign language workshop with 96 students of the "Fundamentals of Physics" class, aiming to raise awareness on the needs of this community in the exercise of the profession; and the design, by a group of nine students, of four different posters highlighting the role of women in Physics, Science and Inventions, which were placed throughout the building.

Responsible for promoting contact and signing agreements with associations, for channelling the demands for participation and solidarity and for seeking the local and global common benefits of the campus community, the Cooperation and Volunteer Office developed several actions within the project:

- $\quad$ Participation of Nursing and Podiatry students in the XX Volunteer Meeting.

- Conference: "Human rights and ethical issues in saving human lives", Open Arms - School of Nursing and Podiatry.

- Presentation of the project: "Black women who changed the world".

During this period, 18 final undergraduate projects and 22 final master's projects related to energy efficiency were developed at the School of Engineering, focusing on energy certification and use of renewable energies (family house, service building, cultural centre, ecological house), renewable energies (wind farms, reuse of natural gas, biomass thermal power plant, solar energy, etc.), electricity consumption (CFL and LED, design of a monitoring system). One of these projects won second place in the 2019 UDC Sustainability contest.

A total of 30 undergraduate and master's projects related to occupational risks were developed at the School of Labor Sciences between 2017 and 2018, with the themes: risk assessment and self-protection in different companies (plastic, naval, sports centres, travel agencies and fisheries) and spaces (theaters, festivals, hotels, administrative buildings and laboratories), occupational stress (nursing professionals, primary school teachers, financial sector workers, women and glass ceiling), punishment actions, emergency plans, risk analysis with contaminants and consequences (asbestos, steel frames, ashes and chemical agents), emergencies, etc.

Another five academic projects related to Healthy Promotion were developed at the Faculty of Nursing and Podiatry, focusing on alcohol consumption among students at the campus, child abuse protocols, smoking cessation and podiatric habits. 
Finally, alongside the use of other social networks as advertising venues, the committee created a webpage to publicize all the Green Campus actions, among which:

- $\quad$ Exhibition on UDC's ecological footprint (Plate 6).

- $\quad$ Training activity on the voluntary carbon market held at the Polytechnical University School, based on a project between Spain and Portugal to increase forest efficiency between the two countries, mitigating climate change.

- $\quad$ Planting trees on the Campus. An olive tree and several lemon trees were planted by Nursing and Podiatry undergraduate students.

- Publication of the book "the gardens of the Esteiro campus". Ferrol campus includes a botanical garden. This book describes the conditions and factors of the location and catalogues the flower species in the botanical garden, with their respective pictures.

- Adherence of the University of A Coruña and, therefore, of the Ferrol campus to the "declaration on the state of the climate and ecological emergency".

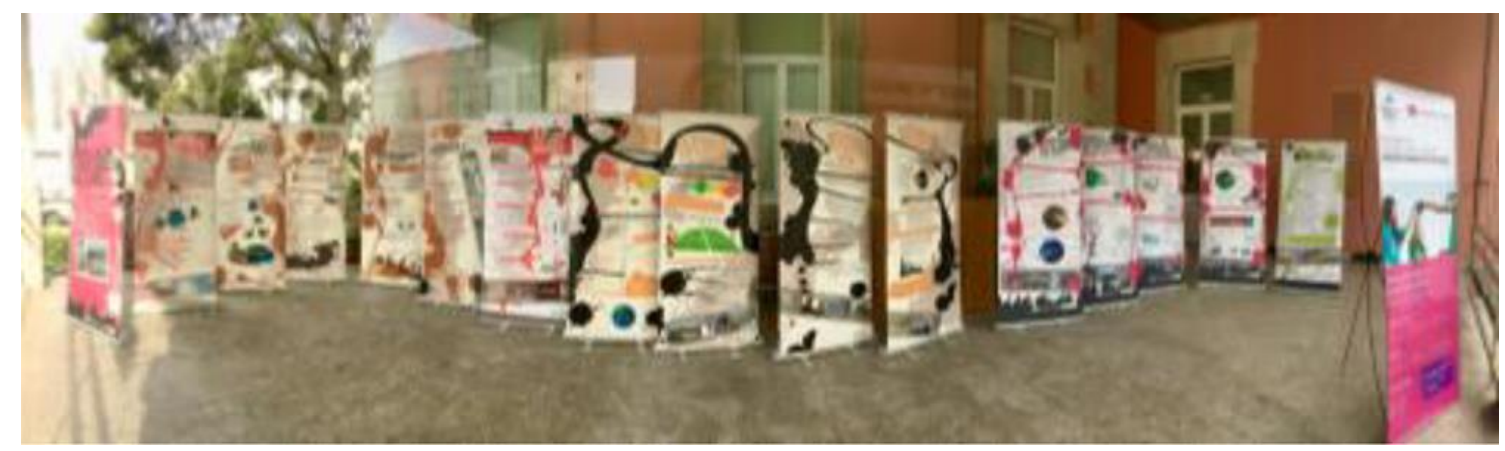

Plate 6. Photograph of the exhibition in the main hall

All the results presented here make up the report sent to the Association for Environmental and Consumer Education (ADEAC). This entity reviewed the campus actions, visited the Campus to conduct an external audit and awarded us the Green Flag. Table 6 shows the list of evidence presented to ADEAC as a justification for the actions carried out on the Campus. 
Table 6. Evidence of the different actions

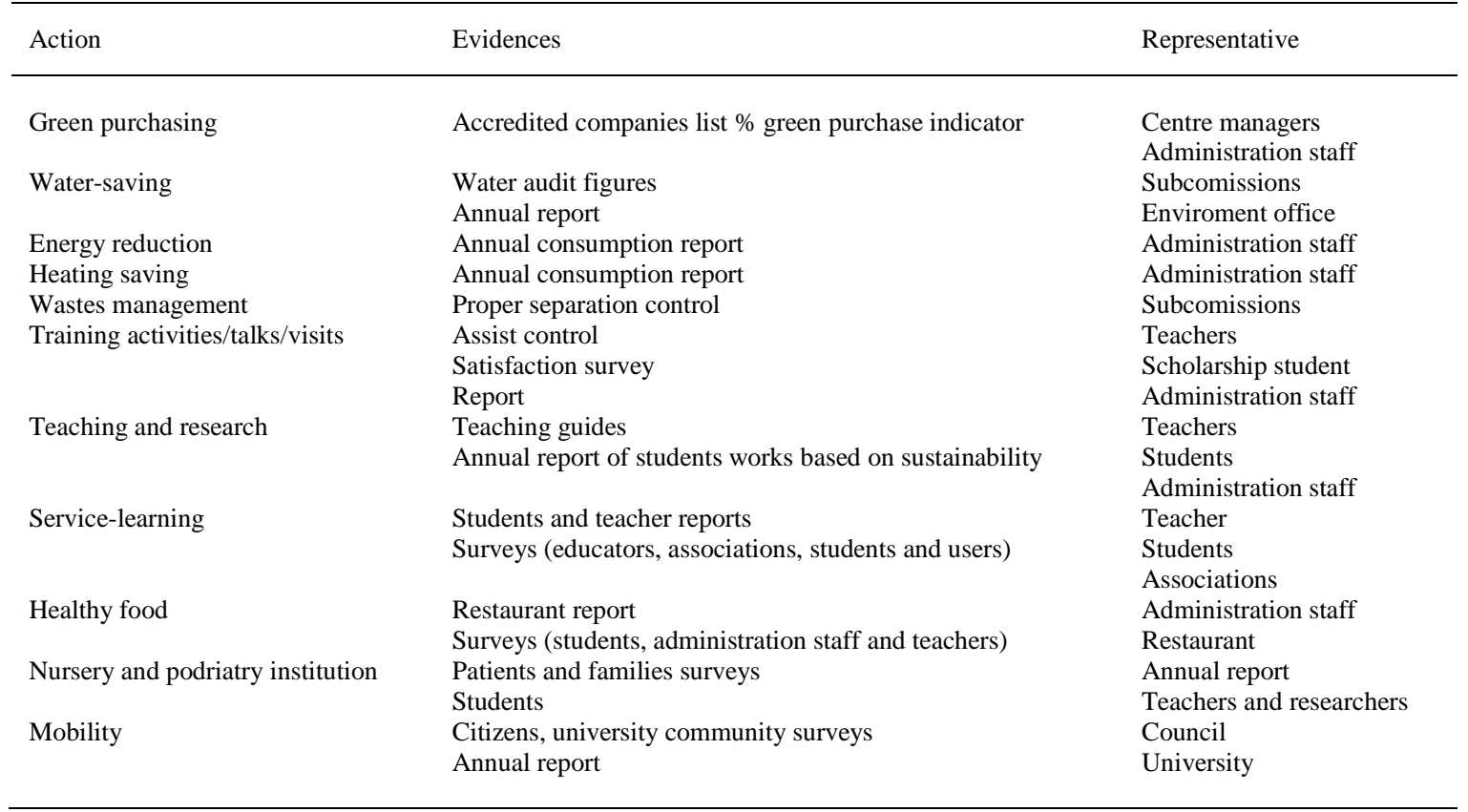

\section{Discussion}

After two years of work to implement the new measures, the Ferrol campus obtained a Green flag after being approved by an external audit. Then, after, important changes took root in campus life.

The consumption of water, electricity and paper showed a significant reduction, while the selective collection on campus was fully implemented. Important issues such as gender equality have become an everyday topic. Ways of thinking and living are changing, driven by changes in mobility, food and physical activities - the campus is now an openly accessible place for studying and sharing quality free time. The service-learning activities allowed students to meet the needs of the community and associations that work with disadvantaged people. All the actors involved (students, entities and users) were very satisfied with the organization, objectives and results. In addition to learning academic skills related to physics, polymers, environment, group work and the development of a project enabled students to improve their collaborative, cooperative and communicative skills. They also achieved civic skills such as empathy, being tolerant and less judgemental and problem-solving skills, learning from those who are different. Different skill sets were needed depending on the workgroup, for example, greater emotional engagement was seen as essential in the most disadvantaged groups (e.g. people with mental illness) (Figure 3). These skills and conclusions emerged from the students' reflections collected during the qualitative analysis. 


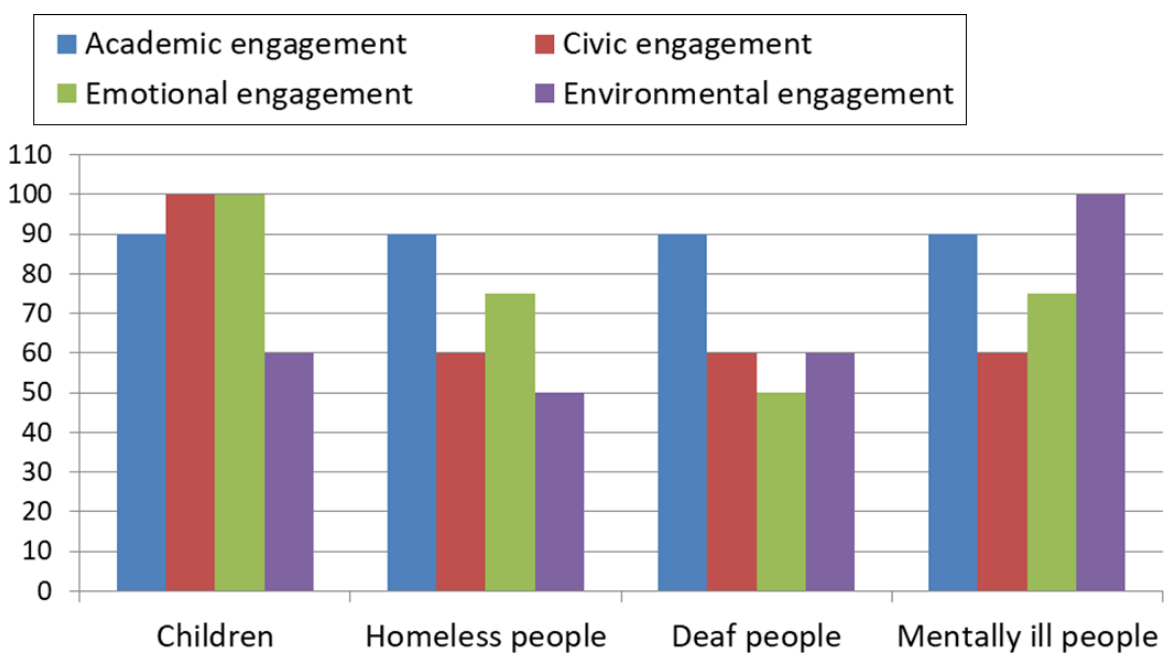

Figure 3. Student skills according to a service-learning project

These activities included four different sustainable development goals: (4) quality education, (10) reduced inequalities, (12) sustainable consumption and production and (17) partnerships for the goals.

At the beginning of this project, students and citizens knew almost nothing about sustainability and social responsibility and were concerned with being able to make a difference, achieve the project's goals, doing something wrong, spending time inefficiently, offending users, not knowing how to interact with users, being unprepared to teach environmental or physics concepts. At the end of the experiment, the students had acquired the skills. From an environmental perspective, students are now conscious of their role, as designers and engineers, in choosing green alternatives (eco-design) to create new products, buildings, machines, etc., and to adapt them to the needs of people with disabilities.

As such, students will start their professional lives knowing more about sustainability and SDGs and being aware of the importance of considering diversity and social justice in their work.

The general population of Ferrol has also learned greatly from this collaborative project. Aside from the positive opinions the experience received from the associations and users regarding their expectations, these people will now share this knowledge with their families, allowing the network of people concerned about the environment to expand.

Many universities have worked to be more sustainable using green technology and clean energy and have made improvements in transportation; others have Campus Green Offices and include Sustainable Development Goals in their programmes. Several projects in the literature promote the relationship between sustainability and social justice using service-learning programmes. The main difference in our project is that it involved people of three different generations and valued the campus-city-community relationship, working together in environmental issues by different service-learning experiences with different entities in the city of Ferrol and by providing different services to citizens such as podiatric care or psychological support to families with chronical illness. To our knowledge, no other university has developed a project connecting sustainability with social justice via service-learning experiences, in the nearby community.

Thus, this was not a conventional experiment to achieve a Green flag, but a project developed on a fully integrated campus, covering the most important aspects of a Sustainable Campus and addressing all issues on waste, energy, health and education. 


\section{Limitations}

Because of institutional support and the growing culture of sustainability in the community, involving students of all ages, administrative staff, professors, political forces and citizens, the experiment faced no major setbacks.

The only significant challenge was linking the inner workings of the centres, which were multiple and involved people with different, sometimes conflicting, ideas. To circumvent this issue, the committee held monthly meetings to discuss measures and contribute ideas.

But what was initially a drawback became our greatest advantage, as the diversity of interests allowed us to create a network that enriched the experience, providing solutions to various problems from different areas and perspectives such as engineering, health and humanities.

\section{Future work}

For future improvements, we suggest including a map with the selective collection points and composting areas on the Campus website and implementing a system for quantifying the waste generated to regularly determine whether the separation of waste is optimal or poor.

It would be fantastic to recognize, by sticker or posters, the best practices of shared use when travelling by private vehicle to the campus, thus encouraging people to share cars.

Comparing non-green campuses and schools to our campus should also yield additional information about the experiment described in this paper (Dagiliüte et al., 2018; Ryan-Fogarty et al., 2016).

\section{Conclusion}

This paper analysed the actions and measures developed by the Ferrol campus in the academic years $2017 / 2018$ and 2018/2019 to achieve a more sustainable and healthy campus. The committee created to oversee the implementation of a green campus established a long-term plan for addressing a better green campus from different perspectives, which can be replicated by other universities. The actions developed can be grouped into three main axes, namely, environment, education and health.

The first axed comprised measures targeting energy efficiency, waste reduction and mobility. Regarding energy efficiency, the experiment obtained a reduction in water consumption between $10.1 \%$ and $79 \%$; electricity was reduced by $40 \%$ using a cloud platform designed by Campus engineers, which could be installed at other universities and public institutions.

Waste reduction was faced on two fronts: the environmental unit designed a system for separating and collecting waste on campus; and the committee organized two visits and five conferences to train students, professors, community members and others on various topics related to the theme. As for transportation, the committee developed a mobility plan together with the municipality and adopted measures aimed at encouraging the use of bicycles.

During this period, several final undergraduate and master's projects related to these areas were developed, namely, 40 projects related to energy efficiency, 30 projects related to occupational risks and seven related to healthy living.

Regarding education, the experiment consisted of modifying teaching guides to include tips on gender equality, responsible consumption, etc., and developing eight different service-learning projects involving 103 students, 205 people with disabilities or at risk of social exclusion and five different community institutions. The Cooperation and Volunteer Office was responsible for promoting these initiatives on and off-campus, contacting entities who work with people with disabilities or at risk of social exclusion. To 
bring university and city closer together, the School of Nursing and Podiatry carried out several actions to offer psychological support to patients and families with chronical illness, diabetes and others.

In the health axis, the UDC Health Office organized 10 different activities to encourage healthy living (conferences, exhibitions, masterclass, etc.) together with several measures in the Campus restaurant to improve the quality of food and reduce waste. Finally, different physical activities were organized on campus involving 835 university members and citizens.

As a result of this experience, the Ferrol campus obtained a Green flag in November 2019. As further work, the committee will continue to suggest new strategies for the green campus, continuously following the Sustainable Development Goals (SDG) developed by the United Nations.

We believe that this experience developed on a medium-sized, young and integrated campus in a small city can serve as a guide to establish the Green Campus philosophy in other similar university campuses, highlighting the campus-city-community relationship, working with both environmental issues (wastes, energy, health and education) and social justice, equality, etc., achieving professionals committed to the future and the commitment of an entire community.

All those involved in this project are protected by the Spanish Data Protection Act, and they and their families, in the case of children, have given their permission to use the photographs taken during work sessions for scientific publications, scientific meetings or any media related to the entities involved or the university.

\section{References}

Abidin, N.I.A., Zakaria, R., Pauzi, N.N.M., Mustaffar, M., Saleh, A.L. and Bandi, M. (2019), "Building energy intensity measurement for potential retrofitting of zero energy building in higher learning institution", IOP Conference Series: Materials Science and Engineering, Vol. 620 No. 1, p. 12070.

Abu Qdais, H., Saadeh, O., Al-Widyan, M., Al-Tal, R. and Abu-Dalo, M. (2019), “Environmental sustainability features in large university campuses: Jordan university of science and tecnhnology (JUST) as a model of green university", International Journal of Sustainability in Higher Education, Vol. 20 No. 2, pp. 214-228.

AdomßNet, M., Grahl, A. and Spira, F. (2019), "Putting sustainable campuses into force: empowering students, staff and academics by the self-efficacy green office model", International Journal of Sustainability in Higher Education, Vol. 20 No. 3, pp. 470481.

Albareda-Tiana, S., Vidal-Raméntol, S. and Fernández-Morilla, M. (2018), "Implementing the sustainable development goals at university levels", International Journal of Sustainability in Higher Education, Vol. 19 No. 3, doi: 10.1108/IJSHE-05-2017-0069.

Alexander, F.K. and Pushnik, J.C. (2017), "Public-public partnerships for a new paradigm in the civic role of the university", Sustainability, Vol. 10 No. 1, pp. 30-38.

Benning, J.L., Surovek, A.E. and Shearer, C.R. (2018), "Engagement in practice: a case study on improving community sustainability through service-learning”, ACM International Conference Proceedings, Vol. 11, pp. 31-349.

Brenna, M., Dolara, A., Foiadelli, F., Leva, S. and Longo, M. (2020), World Sustainability Series, pp. 991-1008.

Bryan, T.W. and Middlecamp, C.H. (2017), "Learning through eating bringing campus dining operations into an environmental science course", Sustainable Solutions: UniversityCommunity Partnerships, Vol. 1, pp. 35-47.

Cabedo, L., Royo, M., Moliner, L. and Guraya, T. (2018), “University social responsibility towards engineering undergraduates: the effect of methodology on a service-learning experience", Sustainability, Vol. 10 No. 1823, pp. 1-17.

Cattaneo, M., Malighetti, P., Morlotti, C. and Paleari, S. (2018), "Students' mobility attitudes and sustainable transport mode choice", International Journal of Sustainability in Higuer Education, Vol. 19 No. 3, pp. 473-497.

Chalfoun, N. (2014), "Greening university campus buildings to reduce consumption and emission while fostering hands-on inquiry-based education", Procedia Environmental Sciences, Vol. 20, pp. 288-297. 
Choi, Y.J., Minjung, O., Jihye, K. and Lutzenhiser, L. (2017), "Plans and living practices for the green campus of Portland state university”, Sustainability, Vol. 9 No. 2, pp. 252-268.

Coleman, K., Murdoch, J., Rayback, S., Seidl, A. and Wallim, K. (2017), "Student's understanding of sustainability and climate change across linked service-learning courses", Journal of Geoscience Education, Vol. 65 No. 2, pp. 158-167.

Cruz, L., Barata, E., Ferreira, J.P. and Freire, F. (2017), "Greening transportation and parking at university of Coimbra", International Journal of Sustainability in Higher Education, Vol. 18 No. 1, pp. 23-38.

Dagiliüte, R., Liobikiené, G. and Minelgaité, A. (2018), WSEAS Transations on Enviroment and Development, Vol. 14, pp. 464-473.

Dienhart, C. (2016), "The impacts of mandatory service on students in service-learning classes", The Journal of Social Psychology, Vol. 156 No. 3, pp. 305-309.

Disterheft, A., Caeiro, S., Azeiteiro, U.M. and Leal Filho, W. (2013), "Sustainability science and education for sustainable development in universities: a way for transition", Sustainability Assessment Tools in Higher Education Institutions: Mapping Trends and Good Practices around the World, Vol. 1, pp. 3-27.

FEE (2019), available at: www.fee.global/

Hamzah, R.Y., Alnaser, N.W. and Alnaser, W.E. (2018), "Accelerating the transformation to a green university", E3S Web of Conferences, University of Bahrain Experience, Vol. 48, p. 8, Article number 06002.

Hayes Lane, S., Huffman, C., Brackney, D.E. and Cuddy, A. (2017), "Going domestic: importing the study abroad experience. The development of a multicultural New York city study away program", Nursing Forum, Vol. 52 No. 3, pp. 196-206.

Keoy, K.H., Fadzil, H. and Masnizan, C.M. (2012), "An exploratory study of readiness and development of green university framework in Malaysia", Procedia - Social and Behavioral Sciences, Vol. 50, pp. 525-536.

Kirrane, M., Pelton, J., Mehigan, C., Poland, M., Mullaly, G. and ÒHalloran, J. (2016), “Approach to transparent sustainability reporting in higher education the experience of a European university in achieving STARS gold", World Sustainability Series 2016, pp. 269-284.

Kowalski, J.A. and Herstek, R.A. (2018), "Engagement in practice: partnering with a local community in an effort to promote revitalization", Journal of Cleaner Production, Vol. 181, pp. 473-482.

Kruger, T.M., McCreary, N., Verhoff, B.L., Sheets, V., Speer, J.H. and Aldrich, S.P. (2018), "College students' understanding of social justice as sustainability", International Journal of Sustainability in Higher Education, Vol. 19 No. 5, pp. 942-962.

Latib, A.A. (2017), "Impact of service learning program to the university and the community", Advanced Science Letters, Vol. 23 No. 1, pp. 596-599.

Leal Filho, W., Shiel, C., do Paco, A. and Brandli, L. (2015), "Putting sustainable development in practice: campus greening as a tool for institutional sustainability efforts", Sustainability in Higuer Education, Vol. 24, pp. 1-19.

Melaugh, B. and Kindschuh, T. (2017), "Engaged in waste: two case studies from Portland state linking operational sustainability and student-community engagement", Nursing Forum, Vol. 52 No. 3, pp. 196-206.

Pereira, G.S.M., Jabbour, C., de Oliveira, S.V.W.B. and Teixeira, A.A. (2014), "Greening the campus of a Brazilian university: cultural challenges", International Journal of Sustainability in Higher Education, Vol. 15 No. 1, pp. 34-47.

Ribeiro, J. (2019), "The perception of students and lecturer of occupational therapy on the importance of involvement in research projects: the MD and GAIT project", The Qualitative Report, Vol. 24 No. 13, Article 9.

Ruiz-Montero, P.J., Chiva-Bartoll, O., Salvador-García, C. and González-García, C. (2020), "Learning with older adults through intergenerational service learning in physical education teacher education", Sustainability, Vol. 12 No. 3, pp. 1-14.

Ryan-Fogarty, Y., Carroll, D., Mahony, M.J. and Regan, B. (2016), "Development of the green campus programme in Ireland: ensuring continuity of environmental education and action for sustainable development throughout the Irish education system", Teaching Education for Sustainable Development at University Level, pp. 269-284.

Sandström, N., Nevgi, A. and Nenonen, S. (2018), "Participatory service design and community involvement in designing future ready sustainable learning landscapes", ASEE Annual Conference and Exposition, Conference Proceedings, 2018, 138114.

Seban, D. (2013), "The impact of the type of projects on preservice teacher's conceptualization fo service learning", Teaching and Teacher Education, Vol. 32, pp. 87-97.

Shribergt, M. and Harris, K. (2012), "Building sustainability change management and leadership skills in students: lessons learned from 'sustainability and the campus' at the university of Michigan", Journal of Environmental Studies and Sciences, Vol. 2 No. 2, pp. 154-164. 
Sima, M., Grigorescu, I. and Balteanu, D. (2019), “An overview of campus greening iniciatives at universities in Romania", International Journal of Sustainability in Higher Education, Vol. 20 No. 3, pp. 410-422.

Soares, N., Pereira, L.D., Ferreira, J., Conceicao, P. and da Silva, P.P. (2015), "Energy efficiency of higher education buildings: a case study", International Journal of Sustainability in Higher Education, Vol. 16 No. 5, pp. 669-691.

UDC (2019), available at: www.udc.es/gl/sociedade/medio_ambiente/GreenCampus/

Voore, S., Srnivas, K. and Pavithr, R.S. (2020), "Smart, digital, green and intelligent campus", IEEE Xplore, 978-1-7281-1253-4/19.

Whitley, C.T. (2015), "Developing social responsibility and political engagement: assesing the aggregate impacts of university civic engagement on associated attitudes and behaviours", Education, Citizenship and Social Justice, Vol. 10 No. 3, pp. 217-233.

Yuhlong, O.S., Ku-Fan, C., Yung-Pin, T. and Hui-I, S. (2018), "How universities can work together with local communities to create a green, sustainable future", E3S Web of Conferences, Vol. 48, Article number 06001.

Zen, I.S., Subramaniam, D., Sulaiman, H., Salen, A.L., Omar, W. and Salim, M.R. (2016), "Institutionalize waste minimization governance towards campus sustainability: a case study of green office initiatives in universiti teknologi Malaysia", ASEE Annual Conference and Exposition, Conference Proceedings, 2016, 123120.

\section{Further reading}

Dheepak, M. and Saravanan, S.V. (2016), "Smart integrated information system (SIIS) for college campus", Journal of Cleaner Production, Vol. 135, pp. 1407-1422.

Iyiegbuniwe, E.A. (2013), "Energy management and sustainability at Western Kentucky University", World Energy Engineering Congress, WEEC, Vol. 2013 No. 2, pp. 1785-1793.

\section{Acknowledgements}

The authors of this article want to thank the finantial and institutional support of Environmental Office of University of A Coruña to develop talks, activities and to implement different actions in Ferrol Campus. The authors of this article want to thank the finantial and institutional support of Vicerrectorado del Campus de Ferrol y Responsabilidad Social of University of A Coruña to achieve the Green Flag. Ana Ares-Pernas wants to thank the financial support of Vicerrectorado de Planificación Académica e Innovación Docente of University of A Coruña obtained in the I Edition of the Prizes for Teaching Innovation Projects in Service-Learning to develop Service-Learning activities. 